\title{
Medidas cautelares pessoais, poder geral de cautela e a taxatividade mitigada
}

\author{
Precautionary measures of personal character, \\ general power of caution and mitigated category list
}

Pedro Machado de Almeida Castro ${ }^{1}$

Professor Voluntário na Universidade de Brasília (UnB) - Brasília/DF

pmacastro@gmail.com

lattes.cnpq.br/6442871646831648

orcid.org/0000-0003-3219-8771

\begin{abstract}
Resumo: Trata-se de estudo que visa a analisar a possibilidade de se adotar uma posição intermediária entre as visões extremas de aplicação de medidas cautelares pessoais no direito processual penal, quais sejam, o poder geral de cautela vs. a taxatividade do rol de medidas aplicáveis. Ou seja, não se pretende analisar requisitos e formas de aplicação das medidas cautelares pessoais, mas, tão somente, se há, ou não, uma liberalidade de criação e aplicação destas medidas, previstas em lei ou não, pelo magistrado.

PalaVRas-chave: processo penal; cautelaridade; poder geral; taxatividade; hermenêutica.
\end{abstract}

ABSTRACT: This is a study that aims to point the possibility of adopting an intermediate vision between the extreme positions of application of personal precautionary measures in the criminal procedural law, namely, the general power of caution vs. closed list of applicable measures. Thus, it is not intended to analyze requirements and forms of application of personal precautionary measures, but only whether or not there is a liberality of creation and application of these measures, provided by law or not, by the magistrate.

KEYWORDs: criminal proceedings; precautionary; general power; list; hermeneutics.

1 Mestre em Direito Processual Penal pela Universidade de São Paulo (USP). Graduado pelo UniCEUB. Editor-assistente da RBCCRIM. Professor-Voluntário na Universidade de Brasília (UnB). Advogado. 
SUMÁRIO: Introdução - 1. Breve histórico - 2. A proporcionalidade como critério de escolha e a questão da taxatividade - 3 . Hermenêutica das normas de processo penal: a interpretação das leis - Conclusão.

\section{INTRODUÇÃo}

A introdução de novas medidas cautelares pessoais diversas da prisão, advindas com entrada em vigor da Lei $n^{0} 12.403 / 2011$, trouxe a necessidade em se aprofundar o debate quanto a forma de aplicação destas medidas.

Isto porque há, em nossa visão, claro equívoco na interpretação dos ensinamentos traçados por González-Cuéllar Serrano (1990, p. 200-201, tradução livre), para quem, ao defender na Espanha aplicação de medidas cautelares alternativas, condicionou esta utilização a três requisitos: "idoneidade e menor lesividade das medidas alternativas; b) legalidade das restrições impostas pelas medidas; e c) existência de infraestrutura para sua aplicação".

Por aqui, é pacífico o entendimento de que toda medida estatal, em sede de direito e processo penal, de caráter restritivo, deve ter sua formatação prévia, escrita, estrita e se dirija a um fim constitucionalmente legítimo. Trata-se dos preceitos do devido processo legal (art. $5^{\circ}$, inc. LIV da Constituição Federal) ${ }^{2}$, legalidade geral (art. $5^{\circ}$, inc. II da Constituição) e penal material (art. $5^{\circ}$, inc. XXXIX, Constituição da República) (MORAES, 2010, p. 315; GONZÁLEZ-CUÉLLAR SERRANO, 1990, p. 78).

Fernandes (2012, p. 60) coloca que “[...] em virtude do princípio da legalidade, estendido ao direito processual penal, não poderia a restrição a direito individual ser admitida sem prévia lei, elaborada por órgão constitucionalmente competente, imposta e interpretada de forma estrita" e sobre o pressuposto da justificação teleológica (ou constitucional), "[...] decorre que a limitação a direito individual só tem razão de ser se tiver como objetivo efetivar valores relevantes do sistema constitucional”.

2 Os constitucionalistas afirmam que seria neste preceito a consolidação própria da proporcionalidade, de maneira autônoma, conforme Gilmar Ferreira Mendes (MENDES; COELHO; BRANCO, 2009. p. 363). 
No presente estudo, impõe-se trazer, assim, a percepção de Badaró (2011b. p. 75) sobre a abertura traçada por González-Cuéllar Serrano:

"Atente-se, contudo, para a premissa da aceitação da aplicação das medidas atípicas 'a pesar de la falta de regulamentación de medidas alternativas en nuestra Ley procesal y sin prejuicio del deseable desarrollo legislativo de alternativas menos gravosas [...]. Ou seja, com o desenvolvimento legislativo e a expressa previsão legal de medidas alternativas, a necessidade de aceitação de medidas atípicas deixa de ter sentido. É o caso brasileiro, posteriormente à Lei 12.403/11"

Desta feita, longe de querer debater os requisitos para aplicação de medidas cautelares pessoais, ${ }^{3}$ pretendemos, aqui, fazer uso da hermenêutica, a fim de se esboçar interpretação lógico-sistêmica, sugerindo um caminho intermediário entre as correntes que defendem o poder geral de cautela $v s$. a taxatividade do rol de medidas aplicáveis.

Isto porque, em nossa visão, ambos os grupos encontram-se em posição por demais extremada, que nada ajudam na aplicação cotidiana do direito.

\section{BREVE HISTÓRICO 4}

"A prisão cautelar é, sem dúvida, a instituição mais cruel e angustiante no paradoxo dramático de todo o processo penal que, como repeti-

3 O que fizemos em nossa dissertação de mestrado.

4 Após o advento do Código de Processo Penal de 1941 - reconhecidamente influenciado pelo Código Rocco, autoritário e repressivo (DELMANTO, 2006. p. 137) -, diversas alterações legislativas importantes ocorreram, transformando-o, paulatinamente, em um código mais humanitário e garantista - Badaró chega a dizer que "[...] não seria exagero afirmar que este [prisão vs. liberdade] foi o tema do Código de Processo Penal em que houve mais mudanças, quer do ponto de vista quantitativo, quer do ponto de vista qualitativo" (2011a, p. 171). Alguns projetos, no entanto, apesar de toda notoriedade e proposta evolutiva, não chegaram a ser aprovados, ou mesmo votados, pelo Congresso Nacional. Os mais conhecidos são o Anteprojeto Hélio Tornaghi, de 1963, o Anteprojeto Frederico Marques, de 1970, e o Anteprojeto de 1981, todos com um pensamento, no tocante à matéria em estudo, mais garantista, prevendo formas mais amenas de acautelar o processo. Deixamos, todavia, de analisá-los detidamente, vez que, apesar das pertinentes discussões e proposições, não chegaram a alterar nossa legislação, como tantos outros projetos de menor porte. 
damente enfatizado, sendo em si mesmo um castigo, se instaura para decidir afinal se é o caso de punir", afirma Pertence (CRUZ, 2011. Prefácio, $\mathrm{XIV}) .{ }^{5}$ Assim, considerando-se que as novas medidas cautelares pessoais - advindas com a Lei $\mathrm{n}^{\circ} 12.403 / 2011$ - traçam um marco no processo penal brasileiro, pertinente fazer um breve incurso histórico das alterações ocorridas em relação à prisão processual e às novas formas de garantir o correto andamento do processo. ${ }^{6}$

Nosso Código de Processo Penal, embora cada vez mais se pareça com uma colcha de retalhos (LOPES JUNIOR, 2011, p. 5), data de 1941, e previa, em seu nascedouro, como única hipótese cautelar pesso-

5 A prisão em si, na antiguidade clássica, surgiu mesmo como uma medida cautelar, sendo que possuía como finalidade única evitar a fuga do acusado e não a penalização, vez que isso só veio a ocorrer séculos depois. Barros coloca: "Na antigüidade clássica a prisão embora tivesse por finalidade fazer atuar a pena definitiva, para a sua efetivação sempre se exigia a evidência do fato, tanto assim que já entre os visigodos a captura era conseqüência da notoriedade do crime. Não obstante, com o advento da Idade Média e a introdução do processo inquisitório, ampliando o poder do magistrado com relação à pessoa do acusado, a prisão preventiva apresentou-se como forma indispensável para imposição da tortura" (1976, p. 223).

6 Do princípio do devido processo legal, estabelecido em consonância com o pensamento libertário da Revolução Francesa, previsto na Declaração dos Direitos do Homem e do Cidadão de 1789, em seu artigo $9^{\circ}$, “[...] resultou a norma inserta na Constituição Imperial de 1824, que em seu art. 179, §§ 8 e 10, dispunha: 'Ninguém poderá ser preso sem culpa formada, exceto nos casos declarados em lei. A exceção do flagrante delito, a prisão não pode ser executada se não por ordem escrita da autoridade legítima. Se esta for arbitrária, o juiz que a deu, e quem a tiver requerido, serão punidos com as penas que a lei determinar'. Diante dessa ordem constitucional, a nossa legislação processual do tempo colonial, condensada nas Ordenações Filipinas, veio a ser substituída, em 1832, pelo Código de Processo Criminal do Império, marco indelével na história do nosso processo penal. Este dispunha em seu art. 175: 'Poderão também ser presos sem culpa formada os que forem indiciados em crimes, em que não tem lugar a fiança; porém, nestes, e em todos os mais casos, à exceção do flagrante delito, a prisão não pode ser executada, senão por ordem escrita da autoridade legítima'. Nesse escorço histórico, atinente ao instituto da prisão preventiva, adquire-se a certeza de que a medida foi sempre facultativa e utilizada para atender os fins do processo, jamais tendo sido lembrada, nem mesmo nas discussões parlamentares ou na doutrina dos praxistas reinícolas, como uma obrigação ao órgão judicante, atendendo à presunção de sua necessidade e conveniência", coloca Barros (1976, p. 223-224). 
al do processo a prisão, que podia decorrer do flagrante, da decretação da prisão preventiva, da decisão de pronúncia, da sentença penal condenatória ${ }^{7}$, ainda que recorrível ou, ainda, do quantum de pena cominado (GOMES FILHO, 2011, p. 33). ${ }^{8}$

No que diz respeito ao flagrante, Barros (1982, p. 119), fazendo referência a Pontes de Miranda, afirma que significa "[...] encontrar alguém na prática do delito, ou em circunstâncias tais que signifiquem estar a praticá-lo, ou no termo do ato delituoso, inclusive havendo fuga”. E explica que o "[...] pressuposto do poder de prender não é, portanto, a flagrância, mas o ser surpreendido na flagrância, demonstrando-se a prevalência do conceito de atualidade sobre o de visibilidade". ${ }^{9}$

Assim, ocorrendo uma das hipóteses do artigo 302 do CPP e lavrado o auto de prisão nos moldes do artigo 304, a custódia era automática, a menos que a infração fosse apenada com multa ou pena privativa de liberdade com máximo inferior a 3 meses, quando o detido deveria, então, ser posto em liberdade após a lavratura do auto. Caso a pena fosse maior, a liberdade poderia ser concedida mediante

7 De se notar que a classificação deste tipo - prisão decorrente de sentença penal condenatória - não tem sua natureza jurídica categorizada de forma unânime. Enquanto a maioria entende ter caráter cautelar (GOMES FILHO, 1992. p. 60; BARROS, 1982. p. 275-278), outros, como Marques (2009. p. 53) e Jardim (2007. p. 266), tem-na como execução provisória, o que pontuamos apenas para conhecimento, vez que não se trata do mote do presente estudo.

8 “[... $]$ com o advento do atual Código do Processo Penal, a 3 de outubro de 1941, o seu art. 312 dispunha: 'A prisão preventiva será decretada nos crimes a que for cominada a pena de reclusão, por tempo, no máximo, igual ou superior a dez anos'. Estava implantada em nosso direito a prisão preventiva compulsória ou obrigatória, impossibilitando ao juiz examinar a necessidade da decretação dessa medida cautelar", como coloca Barros (1976, p. 224). Cruz coloca que "[...] na seara das prisões cautelares, o recrudescimento legislativo foi anunciado expressamente na Exposição de Motivos do Código de Processo Penal de 1941, após a afirmação de que a prisão em flagrante e a preventiva passavam a ser 'definidas com maior latitude do que na legislação em vigor', uma vez que 'o interesse da administração da justiça não pode - dizia-se - continuar a ser sacrificado por obsoletos escrúpulos formalísticos [...]'.” (2011. p. 36).

9 Isto explica, assim, a aceitação da prisão em flagrante nos moldes do inciso IV, do artigo 302, do Código de Processo Penal; enquanto nos demais incisos a visibilidade é pressuposta. 
fiança, salvo as vedações dos artigos 323 e 324 - que hoje, modificados pela Lei $\mathrm{n}^{\circ} 12.403 / 11$, possuem um rol diferenciado (GOMES FILHO, 2011. p. 33).

$\mathrm{O}$ artigo 310 do CPP, modificado pela mesma lei, passou a prever, além das já antigas hipóteses de colocação do réu em liberdade - mediante termo de comparecimento a todos os atos do processo (que se tornou medida cautelar prevista no rol do artigo 319); quando o fato houver sido praticado nas condições excludentes de ilicitude; ou quando ausentes os requisitos da prisão preventiva ${ }^{10}$ - a necessidade de avaliação da possibilidade de aplicação das novas medidas cautelares pessoais, constantes do artigo 319.

A prisão preventiva, decretada pelo juiz de ofício, a requerimento do Ministério Público ou do querelante, ${ }^{11}$ já foi obrigatória nos

10 Esta última, uma inovação trazida pela Lei $\mathrm{n}^{\circ} 6.416 / 77$, cujo teor foi assim comentado por Grinover: "Mas agora, acrescentando um parágrafo único ao dispositivo, a Lei 6.416/77 amplia a possibilidade de liberdade provisória, para abranger, na mesma sistemática, as hipóteses para as quais não se autoriza a prisão preventiva (arts. 311 e 312 do CPP, com a redação determinada pela Lei 5.349/67). Ou seja, haverá possibilidade de liberdade provisória, também no flagrante, sem necessidade de fiança, e mediante termo de comparecimento, quando: a) não houver prova de existência do crime (rectius, do fato criminoso em sua materialidade) e indícios (ou melhor, provas ainda que leves) suficientes da autoria; b) não houver necessidade da prisão para assegurar a aplicação da lei penal. Como se vê, sob a letra $a$ o legislador explicita os casos que podem caracterizar o fumus boni iuris, para efeito de prisão preventiva e manutenção do flagrante; e sob a letra $b$, configura expressamente aquilo que pode representar o periculm in mora" (1977, p. 104).

11 Concordamos com a visão de Badaró, para quem não cabe fixação de medidas, na fase do inquérito policial, por mera representação da autoridade policial, afinal, "não se trata de requerimento, mas de representação. A autoridade policial não é parte. Não formula pretensão alguma. Assim sendo, sua representação não deve ser dirigida ao juiz, mas ao Ministério Público, para que este, considerando-a correta, requeira a prisão preventiva [ou outra medida qualquer]" (2014. p. 735). Nesse mesmo sentido é a Orientação $n^{\circ} 4 / 2014$, lançada pelo Procuradoria Geral da República aos Membros do Ministério Público Federal por meio de sua $7^{\mathrm{a}}$ Câmara de Coordenação e Revisão (controle externo da atividade policial e sistema prisional): "Orienta os membros do Ministério Público Federal a, respeitada a independência funcional, pugnarem pelo não conhecimento de pedido de medida cautelar formulado por autoridade policial diretamente em Juízo, sem o prejuízo de pleitearem a medida cautelar, em petição própria, quanto entenderem 
crimes a que fosse cominada pena de reclusão máxima igual, ou superior, a dez anos, desde que houvesse prova da existência do crime e indícios suficientes de autoria. ${ }^{12}$

A reforma de 1967, com o advento da Lei $n^{0} 5.349$, tornou a decretação deste tipo de prisão facultativa, eliminando o caráter imperioso vinculado à pena abstrata do crime imputado, mantendo-se os demais requisitos. ${ }^{13}$ Foi a Lei ${ }^{0}$ 6.416/77 que eliminou o critério da afiançabilidade, concentrando-se, seu fundamento, na gravidade da infração cometida (GRINOVER, 1977, p. 106). ${ }^{14}$

Outra forma de prisão que desapareceu se dava com a pronúncia, que implicava a necessária custódia do réu, “[...] com recomendação na prisão onde se achasse, ou na expedição de ordem para sua captura,

pertinente" (Disponível em: <http://s.conjur.com.br/dl/recomendacao-mpf-medida-cautelar-pf.pdf > Acesso em: 22 mar. 2017). Em sentido contrário, aceitando a fixação por pedido feito pela autoridade policial, Mendonça (2011, p. 61-62).

12 "Na sistemática do código processual de 1941, dois fatores eram levados em consideração, na decretação da prisão preventiva: a gravidade do crime, que devia ser punido com pena de reclusão, por tempo, no máximo, igual ou superior a dez anos (art. 312, determinando nesse caso a obrigatoriedade da medida); e a afiançabilidade, ou não, dos crimes, pela qual se media a decretação facultativa da medida cautelar. Presente, ainda, devia estar o requisito representado pela garantia da ordem pública, conveniência da instrução criminal ou segurança da aplicação da lei penal, igualmente enquadráveis no periculum in mora (art. 313)" (GRINOVER, 1977, p. 106).

13 Barros assim se manifestou sobre a mudança: “[...] decorridos 26 anos da vigência dessa malsinada norma, de tão triste memória, ainda voltando a normalidade democrática com a Constituição de 1946, somente com o advento da Lei ${ }^{0} 5.349$, de 3 de novembro de 1967, é que essa draconiana forma de medida cautelar desapareceu" (1982, p. 178).

14 "Cabe ressaltar, todavia, que essa proibição de absoluta concessão de liberdade provisória, baseada tão-somente na gravidade do crime perseguido, sem questionar a real necessidade cautela da medida, mostra-se inconstitucional, por violação da garantida da não-consideração prévia de culpabilidade ou da presunção de inocência" (DELMANTO, 2006, p. 139). Além, "[...] não se pode deixar de destacar que, com a Lei $\mathrm{n}^{\circ} 6.416 / 77$, o sistema do CPP perdeu totalmente a coerência. Para os crimes menos graves, era admissível que o investigado ou acusado fosse colocado em liberdade provisória, mediante fiança (CPP, art. 323, inc. I). Já quem cometia crimes graves, poderia ser beneficiado pela liberdade provisória sem fiança, do então inserido parágrafo único do art. 319 do CPP”, conforme Badaró (2011a, p. 174). 
ressalvada a hipótese de crime inafiançável" (GOMES FILHO, 2011, p. 33), nos termos do antigo artigo 408 e parágrafos do Código de Processo Penal. O Código de Processo Penal, quando de sua entrada em vigor, trazia, nos moldes da prisão-pronúncia, o encarceramento decorrente de sentença penal condenatória, ainda que recorrível.

Ainda em período pré-Constituição de 1988, a Lei n ${ }^{0} 5.941 / 73$ (chamada Lei Fleury) abrandou tal obrigatoriedade, apesar de muito aquém das garantias de hoje. Gomes Filho pontua que tais “[...] modificações, embora aparentemente liberalizantes, foram notoriamente ditadas por momentânea conveniência relacionada ao envolvimento de funcionário da alta hierarquia policial em acusações de homicídio"; e completa, explicitando que a introdução de condição de primariedade e bons antecedentes na disciplina da prisão cautelar se deve à sua correspondência “[...] no âmbito da justiça repressiva, a algo próximo à idéia de 'cidadania regulada' segundo a qual os direitos do cidadão decorrem de concessões do poder público" (GOMES FILHO, 1992, p. 63). ${ }^{15}$

Anos se passaram, e foi somente com a reforma processual de 2008 que tais medidas foram extintas, exigindo-se do julgador, como manda a Carta da República, a motivação da manutenção, revogação ou decretação da prisão do réu. ${ }^{16}$ Em relação à pronúncia, foi a Lei

15 E conclui o autor: "Estabeleceu-se, assim, uma duplicidade de fundamentos para a custódia antes da sentença final, que não deixa de dar lugar a perplexidades: antes da pronúncia ou da sentença de primeiro grau, a cognição cautela refere-se ao periculum libertatis, que pode indicar, ou não, a necessidade da prisão; no momento das referidas decisões, deve o juiz proceder a um novo exame da medida, agora voltado à constatação de dados relativos à personalidade do acusado".

16 "Por isso [pelo princípio da presunção de inocência], desde a Constituição de 1988, vozes doutrinárias diziam que as duas modalidades de prisão contrariavam a regra de presunção de inocência do art. $5^{\circ}$, inciso LVII, pois representavam antecipação de pena, não sendo impostas com base em necessidade cautelar assentada em circunstâncias do processo, mas apenas com o sustento no fato de o acusado não ser primário ou não ter bons antecedentes. Ainda, em relação à prisão derivada de sentença, apontava-se outro fundamento de inconstitucionalidade, o de que impor a alguém o recolhimento à prisão para apelar é negar-lhe o direito constitucional ao duplo grau de jurisdição, também garantido por normas da Convenção de San José da Costa Rica (artigos $7^{\circ}$, n. 6, e $8^{\circ}$, n. 10)" (FERNANDES, 2012, p. 308). 
$\mathrm{n}^{\mathrm{0}} 11.6 .89 / 08$ que deu nova redação ao artigo 413, parágrafo $3^{\circ}$, do Código de Processo Penal. Do mesmo modo, no que se refere à prisão decorrente de sentença recorrível, onde a Lei no 11.719/08 disciplinou o procedimento na nova redação do artigo 387 do CPP (já modificado pelo advento da Lei $\mathrm{n}^{\circ} 12.403 / 11$ ), e revogou expressamente o antigo artigo 594.

"A tarefa legislativa de atualização do sistema de medidas cautelares processuais-penais, à luz dos princípios e garantias introduzidos pela Constituição de 1988, foi agora completada - ainda que parcialmente", como coloca Gomes Filho (2011, p. 38). Trata-se da introdução, pela Lei $\mathrm{n}^{0} 12.403 / 11$, de medidas alternativas à prisão cautelar, objeto do presente estudo.

O dever de fundamentação das decisões judiciais, ademais, vem reforçado, mesmo no processo penal, pela entrada em vigor do novo Código de Processo Civil, onde, em seu artigo 489 caput e parágrafo $1^{\circ}$, traz elementos mínimos e essenciais das decisões judicias. ${ }^{17}$

\section{A PROPORCIONALIDADE COMO CRITÉRIO DE ESCOLHA E A QUESTÃO DA TAXATIVIDADE}

A entrada em vigor da Lei $\mathrm{n}^{0} 12.403 / 11$ parece não ter acabado com uma grande discussão que açula os operadores do Direito: o poder geral de cautela no processo penal. Embora forte corrente doutrinária nunca tenha aceitado este poder geral $^{18}$, corriqueiramente se

17 Como coloca Bedê Júnior, "cabe destacar que, embora prevista em dispositivos do CPC, qualquer garantia relevante deve ser aplicada no processo penal. De fato, é inconcebível que o processo civil proteja de modo mais eficiente as partes do que o processo penal. Não existe hierarquia entre cada ramo do direito, porém não se pode perder de vista que as normas processuais que densificam direito fundamentais são, na verdade, heterotópicas e devem ser aplicadas em todas as searas jurídicas. (...) A título de exemplo, os artigos 10 e $489, \S 1^{\circ}$ do CPC, que densificam o princípio do contraditório e da fundamentação das decisões judiciais devem ser aplicados no processo penal." (2016, p. 262).

18 Sempre se mostraram contrários ao poder geral de cautela no processo penal, por exemplo: GOMES FILHO (1992, p. 95); LOPES JUNIOR (2009, p. 8-9); BADARÓ (2011b, p. 75); BOTTINI (2010, p. 26-27); BARROS (1982, p. 58). 
vê sua aplicação pelos tribunais como forma de amenizar as mazelas trazidas pela prisão preventiva, sem, contudo, deixar de acautelar o processo em certa medida. ${ }^{19}$ Há, também, considerável doutrina por sua aceitação. ${ }^{20}$

O poder geral de cautela, assim, nada mais é do que a possibilidade, para os que nele confiam, de que o magistrado se utilize de medidas cautelares inominadas (não previstas em lei) para a segurança processual. Ou seja, poderá o juiz - sempre fundamentadamente (presentes os requisitos do fumus boni iuris e do periculum in mora) - aplicar uma medida que entenda cabível, ainda que não prevista em lei.

A crítica que se fazia, e que vale ainda hoje, de forma a garantir que apenas as medidas previstas sejam aplicáveis, é que “[...] no processo penal, forma é garantia. Logo, não há espaço para poderes gerais, pois todo poder é estritamente vinculado a limites e à forma legal”, coloca Aury Lopes Junior. ${ }^{21}$

Tanto antes, como agora, poderia se cogitar de um poder geral de cautela em consonância com a proporcionalidade, em especial subsunção à adequação, ou proibição do excesso, vez que nenhuma medi-

19 LOPES JUNIOR, 2009, p. 8-9; BOTTINI, 2010, p. 26-27. Badaró explicita que "[...] antes, quando vigorava o reducionismo bipolar, argumentava-se, ante a inaceitável omissão legislativa, com a possibilidade de o Juiz penal, aplicando por analogia (CPP, art. $3^{\circ}$ ) o poder geral de cautela previsto no Código de Processo Civil (CPC), decretar medidas cautelares processuais atípicas, isto é, não previstas em lei. E, complementando-se tal raciocínio, fundamentava-se a necessidade de se socorrer de medidas não previstas em lei, in bonam partem, isto é, para beneficiar o acusado, pois, caso contrário, teria o Juiz que decretar a sua prisão preventiva ou mantê-lo preso em flagrante delito" (2011b, p. 72).

20 Aceitando o poder geral, inclusive hoje, ainda que de forma temperada: CRUZ, 2011, p. 178; MENDONÇA, 2011, p. 80; LIMA, 2012, p. 565.

LOPES JUNIOR, 2009, p. 8. E completa o autor: "Esclareça-se que nossa crítica ao poder geral de cautela não se esvaziará com mudanças legislativas, pois elas apenas ampliarão o leque de medidas cautelares, sem jamais poder contemplar uma cláusula geral, deixando ao livre arbítrio do juiz criar outras medidas além daquelas previstas em lei. Nesta linha, os Projetos de Lei 4208-C e o PL 156/2009 (Anteprojeto de CPP) instituem um modelo polimorfo, em que o juiz poderá dispor de um leque de medidas substitutivas da prisão cautelar. Mas, sublinhe-se, igualmente estará atrelado ao rol de medidas previstas em lei, não podendo criar outras medidas além daquelas previstas no ordenamento." 
da é perfeitamente adequada a todos os casos concretos, sendo certo que, independentemente do número de medidas previstas, sempre se pensará em uma alternativa - supostamente - melhor e mais benéfica ao acusado. ${ }^{22}$

Entretanto, como se sabe, o postulado da proporcionalidade, em sua maioria aceito sob os traços esboçados por Nicolas GonzálezCuéllar Serrano (1990) (adequação, necessidade e proporcionalidade strictu sensu), adotado por nós, jamais se esquivará do princípio da legalidade. ${ }^{23}$

Nesse ponto, a taxatividade implica que todas as medidas cautelares estejam previstas em lei, ou seja, que sua aplicação esteja condicionada às hipóteses expressamente previstas em lei (MENDONÇA, 2011. P. 79).

Ocorria, antes da reforma, por vezes, a falaciosa necessidade de imposição de uma medida diversa (e não prevista), como v.g. a entrega do passaporte, sob o pretexto de acautelar o processo, muito embora a prisão não se mostrasse adequada, ou mesmo, necessária. Argumentava-se que, assim, o acusado não sofreria constrição maior

22 BADARÓ, 2011b, p. 73. No sentido, aceitando o poder geral de cautela temperado, Andrey Borges de Mendonça pontua: "Isto porque a realidade é muito mais ampla e variada que a imaginação do legislador. Haverá situações concretas que sequer foram imaginadas pelo legislador, em que o magistrado se verá diante de situações de risco que terão que ser enfrentadas. Nestes casos, surgirá a importância do poder geral de cautela" (2011, p. 80).

${ }^{23}$ Neste sentido, Badaró coloca: "A adoção de medidas atípicas, porque não previstas em lei como aptas a privar ou restringir o direito de liberdade em sede de medida cautelar, encontra inafastável barreira no pressuposto formal do Princípio da Legalidade. Ainda que a medida seja adequada, necessária e proporcional, se a restrição ao direito fundamental não estiver prevista em lei, não será legítima" (2011b, p. 75). Em sentido contrário, no entanto, temperando o poder geral de cautela, Cruz aduz "[...] que não se poderá subtrair do julgador a possibilidade de fazer uso de seu poder geral de cautela, de forma excepcional, tendo como objetivo evitar a prisão preventiva. Poderá o magistrado, então, impor ao investigado ou acusado medida que, embora não conste literalmente do rol positivado no artigo 319 do CPP, seja prevista em outra norma do ordenamento, ou possa ser considerada, por meio de interpretação extensiva, abrangida na dicção de algum dos incisos que compõem o elenco das cautelares pessoais diversas da prisão, previstas no referido dispositivo" (2011, p. 183). Acompanhado por: Mendonça (2011, p. 79-84). 
[prisão!], sendo, desta maneira, uma cautelarização mais benéfica (LIMA, 2012, p. 568-569).

Todavia, como aponta Badaró (2011b, p. 79), “[...] corretamente estabelecidas as premissas, não se tratava de medidas atípicas para 'beneficiar o acusado' [...], mas de medida atípica que restringia seu direito de liberdade mais do que o permitido em lei". ${ }^{24}$ E completa, este autor (2011b, p. 79), que o mesmo raciocínio se aplica ao rol das novas medidas cautelares alternativas à prisão, afinal, nesta lista, há que se buscar aquela menos gravosa que atente ao fim almejado:

"[...] se nem mesmo a menos intensa das medidas se mostrar adequada à gravidade do crime, circunstâncias do fato e condições pessoais do indiciado ou acusado (art. 282, caput, inciso II), é porque, no caso, não se deve impor qualquer medida cautelar alternativa à prisão."

$\mathrm{O}$ antigo argumento de aplicação analógica (CPP, art. $\left.3^{\circ}\right)$ do poder geral de cautela previsto no antigo artigo 798 do velho CPC (hoje previsto no art. 301 do novo CPC) não pode prosperar. Conquanto a intenção era a suposta aplicação in bonam partem, não é o que ocorre; o discurso se esvazia, também, com a criação de um rol de medidas ante a entrada em vigor da Lei ${ }^{0} 12.403 / 11 .^{25}$

24 “Assim sendo, se as alternativas legais eram a prisão ou a liberdade, e a prisão não se mostrava adequada, outro caminho não restaria, no marco da legalidade, que a concessão da liberdade provisória, no caso de prisão em flagrante delito, ou a não decretação da prisão preventiva, com a manutenção da liberdade plena, nos demais casos" (BADARÓ, 2011c, p. 2.228). Nesse sentido: Kehdi (2007).

Se o argumento era a falta de medidas alternativas, a criação de um extenso rol não pode ser renegada sob o pretexto de que "[...] a realidade é muito mais ampla e variada que a imaginação do legislador" (MENDONÇA, 2011, p. 80). Nesse sentido, embora ainda pendente ao poder geral de cautela, Lima coloca, em pensamento anterior à promulgação da Lei $n^{0} 12.403 / 11$ : "A solução, para nós, seria a promulgação de uma reforma processual penal onde se restasse prevista uma gama maior de medidas cautelares não prisionais, como vem ocorrendo em outros países, tornando-se assim não necessária a utilização do poder geral de cautela. Contudo, é de ser que, mesmo com a criação ampla de medidas cautelares, sempre poderá ocorrer que, para determinado caso concreto, se faça necessária uma cautelar específica, já que é impossível 
O uso da analogia e dos princípios gerais do Direito, ainda, constantes do enunciado no artigo $3^{\circ}$ do CPP, não podem subsistir, também, por outra razão. A Constituição da República assegura o direito à liberdade (art. $5^{\circ}$, caput) e o devido processo legal (art. 5o, inc. LIV), assim como as garantias constantes de tratados internacionais concernente aos direitos humanos $\left(\operatorname{art.} 5^{\circ}, \S \S 2^{\circ}\right.$ e $\left.3^{\circ}\right)$.

Neste diapasão, o artigo 7.2 da Convenção Americana sobre Direitos Humanos, garantindo o princípio da legalidade das medidas cautelares (BADARÓ, 2011b, p. 80), afirma que “[...] ninguém poderá ser privado de sua liberdade física, salvo pelas causas e nas condições previamente fixadas pelas constituições políticas dos Estados-partes ou pelas leis de acordo com elas promulgadas". ${ }^{26}$ Tem-se, desta feita, disciplina legal no que concerne ao processo penal, sem a necessidade de nos socorrermos ao processo civil. ${ }^{27}$

Como colocam Ramírez e Malarée (1997, p. 87), tratando do princípio da legalidade aplicado ao processo penal, "se trata que la actividad judicial no exceda de lo que estrictamente estabelece la ley y de excluir toda posibilidad de arbitrariedad en el processo."

Por tudo quanto exposto, não há que se cogitar de um poder geral de cautela no processo penal. Afinal, “[...] para além das boas intenções dos juízes (e quem nos protege da bondade dos bons?)", repita-se Lopes Junior (2009): “[...] no processo penal, forma é garantia”.

que se esgotem todas as hipóteses abstratas imagináveis em previsão legislativa" (2012, p. 133).

26 "Ressalte-se, ainda, que embora o artigo 7.2 se refira à 'privação de liberdade', este dispositivo tem sido interpretado com amplitude pela Corte Interamericana de Direitos Humanos (CIDH), de forma a compreender não apenas a privação da liberdade, mas também o caso de restrição da liberdade" (BADARÓ, 2011c, p. 231).

27 Afinal, como o próprio artigo $3^{\circ}$ do CPP preceitua, “[... ] a lei processual penal admitirá interpretação extensiva e aplicação analógica”; entretanto, como explicita o artigo $4^{\circ}$ da Lei de Introdução às Normas do Direito Brasileiro: “[...] quando a lei for omissa, o juiz decidirá o caso de acordo com a analogia, os costumes e os princípios gerais de direito.” Assim, somente se utiliza da analogia, "quando a lei for omissa”, o que não é o caso. Para que se possa utilizar da analogia, que é uma forma de preenchimento da lacuna da lei, é necessário que haja omissão. Nesse sentido: TOURINHO FILHO, 2012, p. 201-206. 
Por outro lado, diferentemente de um poder geral de cautela, há que se analisar a possibilidade de interpretação extensiva dos ditames legais previstos no Código de Processo Penal, ou mesmo, a aplicação de determinadas medidas cautelares pessoais previstas em leis esparsas a casos análogos. Tudo, sem perder de vista o princípio da legalidade e o critério da proporcionalidade.

\section{HERMENÊUTICA DAS NORMAS DE PROCESSO PENAL: A INTERPRETAÇÃO DA LEI}

O processo não é um fim em si mesmo, mas meio de dispor na conformidade do que regula a lei de maneira geral. "Mais do que qualquer outra norma jurídica, a lei de processo penal se destina a conciliar a necessidade de Segurança com a exigência de Justiça”, coloca Tornaghi (1977, p. 69) ${ }^{28}$ E nessa conciliação entre Segurança e Justiça, o autor coloca que a solução não pode ser apriorística, mas variável conforme o momento que atravessa uma sociedade. Em sendo maior a exigência de Segurança, necessário um Estado mais forte (que é maior quando o juiz se prende à lei); em não havendo risco de perturbação da ordem, um Estado liberal pode se mostrar mais adequado a seus fins (que pode ser aprimorada com certo temperamento das leis) (TORNAGHI, 1977, p. 73-75).

Sobre a variação de tempo e conteúdo, Mello (1972, p. 141147) coloca que "[...] instrumental que é o Direito, seu conteúdo varia de acordo com as épocas, de acordo com os lugares, de acordo com os pontos-de-vista políticos dominantes em cada época. O conteúdo do

28 E completa: “A justiça é para o Direito o que o belo é para a arte: valor supremo, meta perseguida, arquétipo que informa toda a obra realizada. É possível que varie o conceito de belo, a apreciação subjetiva do belo; da mesma forma a idéia de justiça difere de uma para outra cabeça; ela pode e deve diversificar para adaptar-se à variação dos costumes e à forma das instituições, sem que a Justiça em si mesma seja arranhada. O que ocorre aqui é igual ao que sucede com o belo: o que é bonito num fundo escuro pode não ser num fundo claro. E assim como um quadro ou uma composição musical eventualmente consagram o feio, o desgracioso, da mesma forma também a lei pode conter o iníquo, porque o real às vezes foge do ideal, quer por erro de concepção, quer por desvirtuamento da vontade" (TORNAGHI, 1977, p. 69). 
Direito varia, não o Direito; o conteúdo dos mandamentos se altera, mas o Direito é como que o invólucro, capaz de reter dentro de si os mais variados conteúdos". ${ }^{29}$

Assim, o formalismo está mais na forma que no conteúdo do Direito, sendo a regulamentação de cabimento, configuração, lugar, tempo, competências dentre outras características do ato processual, como vimos, por lei. A inobservância da norma constitui ilegalidade. ${ }^{30}$

Entretanto, a formulação da regra jurídica se mostra, muitas das vezes, complexa, intrincada, com idas e vindas, de difícil compreensão ou fora da lógica de uma construção retilínea, com diversas emendas e substitutivos, dificultando o reconhecimento da vontade do legislador, "[...] sem que um órgão do Estado a declare de forma concreta e individualizada" (TORNAGHI, 1977, p. 83). ${ }^{31}$

Para tanto é que se presta a hermenêutica jurídica. ${ }^{32}$

29 E sobre a instrumentalidade do Direito (e não do processo), coloca: "O Direito não é senão aquele instrumento que regulamenta os comportamentos humanos na vida social. Em outras palavras, e do modo mais singelo possível, poderíamos dizer que o Direito é meramente um aparelho de coação, é um instrumento de coação. É um instrumento através do qual são reguladas situações e comportamentos, não apenas comportamentos, como de hábito supomos”. (MELLO, 1972, p. 141-147)

30 “O Estado de Direito ‘desconfia de si mesmo', teme o abuso de poder, procura limitar-se e demarcar as atribuições de seus órgãos; prescreve a forma, o lugar e o tempo dos atos processuais. Nisso consiste o formalismo e essa é a sua significação. Não deve ser entrave à justiça, mas tem de acautelar a segurança. [...] Convém que o procedimento seja rápido e econômico; mas é indispensável que conduza à paz com justiça. Importa, entretanto, nunca perder de vista que as formas processuais são meio e não fim" (TORNAGHI, 1977, p. 77).

31 Maximiliano aponta: "Resulta imperfeita a obra legislativa; porque as Câmaras funcionam com intermitência, deliberam às pressas, e não atendem somente aos ditames da sabedoria. Preocupam-se, de preferência, com alguns tópicos; fixado o acordo sobre estes, deixam passar sem exame sério os restantes: descuram do fundo, e talvez mais da forma, que é a base da interpretação pelo processo filológico" (2000, p. 119).

32 Sobre a aplicação do Direito: "Nenhum aplicador do direito, por isso mesmo, conseguirá êxito na sua missão se se limitar à pura e simples aplicação dos textos legais em vigor. A infinita variação dos fatos humanos só encontrará a justa solução buscada pelo ideal do direito se o aplicador souber encontrar no espírito do ordenamento jurídico a norma individualizada que cada caso concreto reclama" (THEODORO JÚNIOR, 1981). Segundo Maximiliano citado por Queiroga: "A hermenêutica, na lúcida visão de Carlos Maximiliano, 


\subsection{INTERPRETAÇÃO DAS LEIS}

"Interpretar a lei é descobrir ou revelar a vontade contida na norma jurídica ou, como diz Clóvis, é revelar o pensamento em que anima as suas palavras", coloca Tourinho Filho (2012, p. 193). ${ }^{33}$

O que se busca com isto, no entanto, é o conteúdo da lei, voltando-se para sua inteligência e vontade, fim para o qual foi criada. Não se trata de descobrir a intenção do legislador, "[...] pessoa imaginária, cuja vontade dificilmente se chega a saber que coisa é, até porque o legislador é, na maioria dos casos, um órgão coletivo em que cada componente, como pessoa física, tem vontade própria e possivelmente diversa da dos demais", preceitua Barros (1969, p. 86).

\subsubsection{TIPOS DE INTERPRETAÇÃO}

Desta feita, do ponto de vista subjetivo, ou seja, do sujeito que interpreta a norma, esta pode ser autêntica, doutrinal ou judicial.

'tem por objeto o estudo e a sistematização dos processos aplicáveis para determinar o sentido e o alcance das expressões do Direito'. [...] Carlos Maximiliano, no entanto, nos dá uma significação de hermenêutica, em seu sentido amplo. Nesse caso, abrange a interpretação e integração, e, quiçá, a própria aplicação que é a finalidade última de toda interpretação e integração” (QUEIROGA, 1980, p. 31-40).

33 Ávila pontua: "De um lado, a compreensão do significado como o conteúdo conceptual de um texto pressupor a existência de um significado intrínseco que indefensa do uso ou da interpretação. Isso, porém, não ocorre, pois o significado não é algo incorporado ao conteúdo das palavras, mas algo que depende precisamente de seu uso e interpretação, como comprovam as modificações de sentidos dos termos no tempo e no espaço e as controvérsias doutrinárias a respeito de qual o sentido mais adequado que se deve atribuir a um texto legal. Por outro lado, a concepção que aproxima o significado da intenção do legislador pressupõe a existência de um autor determinado e de uma vontade unívoca fundadora do texto. Isso, no entanto, também não sucede, pois o processo legislativo qualifica-se justamente como um processo complexo que não se submete a um autor individual, nem a uma vontade específica. Sendo assim, a interpretação não se caracteriza como um ato de descrição de um significado previamente dado, mas como um ato de decisão que constitui a significação e os sentidos de um texto" (2011, p. 31). 
Para os fins a que se destina o presente trabalho, interpretação autêntica, em linhas gerais, é aquela realizada pelo próprio legislador. ${ }^{34}$ Doutrinal, como o próprio nome já diz, é aquela feita pelos juris scriptores, pelos doutrinadores do Direito, enquanto a jurisprudencial, também auto-explicativa, é aquela levada a efeito pelos juízes e tribunais (TOURINHO FILHO, 2012, p. 194). ${ }^{35}$

Do ponto de vista objetivo (e mais importante ao nosso estudo), no entanto, os meios empregados para se proceder à interpretação se distinguem em gramatical (ou literal), lógico (ou teleológico) e sistemático (ou histórico). ${ }^{36}$

Assim, a interpretação gramatical preocupa-se com as diversas acepções que o vocábulo pode ter. Hoje, tem menos importância para o Direito moderno do que já se atribuiu em tempos antigos. ${ }^{37}$

34 "A doutrina distingue a interpretação autêntica em contextual e por lei posterior. Se a interpretação é feita no contexto, 'mediante disposiciones que mutuamente se aclaran', diz-se contextual [...]. Se a interpretação se dá por lei posterior - o que constitui a regra -, fala-se em interpretação 'por lei posterior'." (TOURINHO FILHO, 2012, p. 194).

35 Essa, também, de valoroso significado para nosso estudo, vez que deve ser a concretizadora de nossas conclusões. Ávila elucida: “(...) é necessário ultrapassar a crendice de que a função do intérprete é meramente descrever significados, em favor da compreensão de que o intérprete reconstrói sentido, quer o cientista, pela construção de conexões sintáticas e semânticas, quer o aplicado, que soma àquelas conexões as circunstâncias do caso a julgar; importa deixar de lado a opinião de que o Poder Judiciário só exerce função de legislador negativo, para compreender que ele concretiza o ordenamento jurídico diante do caso concreto" (2011, p. 34).

36 Tourinho Filho anota que “[...] do ponto de vista objetivo, isto é, levando-se em conta os meios ou expedientes intelectuais empregados para se proceder à interpretação, esta se distingue em gramatical ou literal, lógica ou teleológica, sistemática e histórica. Outros autores preferem dizer que os elementos "histórico" e "sistemático" são considerados na interpretação lógica ou teleológica" (2012, p. 195). Nos filiamos, assim, a esta outra corrente, por entender que o processo de interpretação lógica, como veremos, perpassa pela análise histórica e sistemática da lei e sua criação. Embora faça a separação, Tornaghi parece assim proceder mais para fins didáticos, pois assim disciplina: " $E$ ainda para conhecer a finalidade da norma é útil o estudo de sua gestação, de sua elaboração, de seus precedentes, dos trabalhos preparatórios. É a interpretação histórica. Ela busca conhecer a vontade do legislador [...]” (1977, p. 128).

37 "Tem menos importância para o Direito moderno do que lhe atribuíam para o antigo, escrito em línguas mortas. Nesse caso não se deparavam só com 
"Se os termos usados têm acepção técnica, ainda que convencional, deve ela ser adotada pelo intérprete. Não, entretanto, nas hipóteses em que se saiba ter sido empregada com o significado vulgar ou pelo menos sem preocupação técnica", afirma Tornaghi (1977, p. 126). ${ }^{38}$ Assim é que se mostra necessário, em geral, a utilização de mais de um meio de interpretação para se chegar ao fiel cumprimento da lei. ${ }^{39}$

O processo gramatical pode ser o primeiro na ordem metódica, porém, em importância, a interpretação, por excelência, é a que se baseia no fim almejado, no modelo ideológico (MAXIMILIANO, 2000, p. 121). Daí surge a interpretação teleológica, visando que se pesquise o fim colimado pela norma legal. Do grego telos = final, enquanto teleologia $=$ o estudo das causas finais (TORNAGHI, 1977, p. 127).

Isto posto, pretende-se, através desta forma de interpretação, fazer um estudo da norma em si, além do conjunto de normas do sistema jurídico, por meio do raciocínio dedutivo (MAXIMILIANO, 2000, p. 123).

dificuldades possíveis de resolver com o auxílio de gramáticas e dicionários; surgiam graves problemas filológicos, dúvidas oriundas das variantes de edições ou diversidade de manuscritos, e outras controvérsias em que a Hermenêutica necessitaria aliar-se à Crítica erudita para se aproximar o mais possível da verdade" (MAXIMILIANO, 2000, p. 107).

Como exemplo, o autor coloca: "Isso acontece, frequentemente, nas Constituições que usam com o sentido corrente vocábulos que em determinado ramo do Direito têm significação própria. Assim, por exemplo: a palavra indulto, no art. $81, \mathrm{n}^{\circ}$ XXII, da Constituição Brasileira está usada como perdão, em geral, sem atenção para o significado técnico dessa palavra em Direito penal (indulto = perdão coletivo; graça = perdão individual); [...]".

39 Tornaghi aponta o cuidado que teve o legislador italiano ao dispor no artigo 12 das "Disposições Preliminares" do Código Civil italiano que "Ao aplicar a lei, não se lhe pode atribuir outro sentido senão o que ressalta o significado próprio das palavras segundo sua conexão e a intenção do legislador" [tradução do autor]. E completa: "Cumpre não esquecer que a interpretação puramente gramatical faz da letra um cadáver. Com abundância de exemplos, mostra Ihering que "na interpretação das leis, a jurisprudência antiga não seguia o texto cegamente, sem se preocupar com o resultado. Bem ao contrário, tinha ela o olhar permanentemente voltado para as necessidades da vida prática e sabia interpretar as leis em coerência com essas necessidades'." (1977, p. 125-127). "Quem só atende à letra da lei, não merece o nome de jurisconsulto; é simples pragmático (dizia Vico)”, coloca Maximiliano (2000. p. 112). 
Tourinho Filho (2012, p. 196) coloca que se dá este tipo de interpretação quando o intérprete "[...] se serve das regras gerais de raciocínio para compreender o espírito da lei e a intenção do legislador [...], porquanto visa precisar genuína finalidade da lei, a vontade nela manifestada".

Conquanto alguns doutrinadores separam esta interpretação da sistemática e da histórica, entendemos que a apreciação do fim inserto na lei ou a vontade do legislador só podem ser alcançadas passando por tais etapas - histórico-sistêmica -, de forma que devem fazer parte da interpretação teleológica.

Assim, “[...] quando a dúvida não recai sobre o sentido de uma expressão ou de uma fórmula da lei, mas sim sobre a regulamentação do fato ou da relação sobre que se deve julgar" (TOURINHO FILHO, 2012, p. 197), utiliza-se a apreciação sistêmica. ${ }^{40}$

Já a investigação histórica se dá quando há pesquisa do processo evolutivo da lei, seus precedentes, o projeto de lei, as discussões havidas durante o seu processo de elaboração, a Exposição de Motivos etc.

Interpretar a norma, destarte, tem por fim aclarar o sentido que lhe haja dado o legislador. Em regra, tem como consequência a declaração; visa tão somente a elucidar a norma interpretada.

Ocorre, muitas vezes, que a lei pode dar a entender mais do que pretendia, ou, em tantas outras, dizer menos do que deveria ter feito. Surge uma subclassificação das formas de interpretação das normas, de maneira que a compreensão pode ser, ainda, restritiva ou extensiva. ${ }^{41}$

\subsubsection{AMPLITUDE DAS FORMAS INTERPRETATIVAS}

Como vimos, a forma mais comum de interpretação é a declarativa, que se atém a iluminar o quanto estipulado pela norma jurídica.

40 Tornaghi coloca que “[...] separada do conjunto, uma norma pode, às vezes, apresentar um sentido que desaparece quando ela é confrontada com as demais, que, inclusive, frequentemente a limitam ou alargam, determinam ou qualificam, modulam ou condicionam" (1977, p. 128).

41 Barros coloca-as como Classificação (1969, p. 93); Tourinho Filho como Resultado (2012, p. 197), enquanto Tornaghi como Natureza e Alcance da interpretação (1977, p. 129). 
A perspectiva restritiva deve diminuir a aparente extensão da norma, quando esta tiver dito, em geral de maneira genérica, mais do que pretendia o legislador, ou poderia se dar o alcance da norma (MAXIMILIANO, 2000, p. 198). ${ }^{42}$

Extensiva é a interpretação que, utilizando-se da interpretação teleológica (e suas vertentes histórica e sistêmica), torna a norma aplicável também aos casos não previstos no teor de sua literalidade (BARROS, 1969, p. 94).

Sobre o tema, mister os dizeres de Carlos Maximiliano (2000, p. 200), quando afirma: "Nenhuma norma oferece fronteiras tão nítidas que eliminem a dificuldade em verificar se se deve passar além, ou ficar aquém do que as palavras parecem indicar".

Feitas estas breves considerações, devemos tentar responder à problemática exposta ao final do item 2 retro.

\section{CONCLUSÃO - A CORRETA LEITURA DE ALGUNS PRECEITOS LEGAIS E A INTERPRETAÇÃO EXTENSIVA}

De tudo quanto exposto, cremos ser possível, para preencher a exigência cautelar do caso concreto, que se faça uso da interpretação extensiva e se aplique medidas acauteladoras previstas em leis esparsas a casos cuja tipificação não se encontram em tais leis. É o que podemos chamar de taxatividade mitigada.

Isto porque, como vimos, o processo legislativo se mostra intrincado, de forma que, por vezes, a evolução do pensamento não acompanha a produção das leis, v.g. as medidas protetivas previstas na Lei no 11.340/06 (Lei Maria da Penha), fruto da evolução do pensamento de criação de medidas alternativas e que, apesar de pensada após o projeto de lei que ensejou a inserção das novas medidas cautelares (Projeto de Lei $\mathrm{n}^{\mathrm{o}} 4.208 / 01$ ), viu-se promulgada anteriormente

42 "É quando delimita a esfera dos casos previstos pela norma, ou declara-se que não abrange a casos nela não especificados”, afirma Barros (1969, p. 94). 
àquele. Eis a razão para que se aceite a aplicação de medidas de resguardo constantes de leis avulsas. ${ }^{43,44}$

43 Lima, colocando-se sobre o princípio da codificação e leis extravagantes, assim se pronuncia: "É de boa técnica legislativa, mormente no sistema penal que, pelo princípio da codificação, os delitos devam ser agrupados em um código, o que é a regra, objetivando a não proliferação de leis esparsas, e o mesmo se aplica em relação às regras processuais, facilitando a melhor dedução da pretensão punitiva em Juízo. [...] A sistematização penal é uma conquista científica obtida através dos séculos, desde o antigo Direito Romano. Entretanto, no Brasil, ultimamente, tem ocorrido a proliferação de leis especiais em matéria penal, sem a necessária sistematização e coerência de técnica legislativa, deixando perplexos doutrinadores e aplicadores do Direto Penal. [...] E, via de regra, tais leis extravagantes, além de normas materiais ou tipos penais, vêm dispondo, impropriamente, sobre normas processuais, criando-se assim, um misto de normas penais e processuais penais especiais, em uma só lei, aplicadas àqueles casos específicos" (2001, p. 5-7).

${ }^{44}$ Da mesma forma que aqui se critica a previsão difundida de medidas cautelares, restringindo seu âmbito de aplicação, em Portugal também se o fez, quando das reformas operadas nos anos de 2007 a 2010, onde, embora a previsão de aplicação de detenção fora do flagrante delito exigisse pena máxima cominada superior a 5 anos, leis esparsas, como a lei de armas e lei que estabelece o regime de prevenção da violência doméstica vieram a permitir tal aplicação em hipóteses cuja pena máxima cominada ao crime em tese fosse de apenas 3 anos. Assim, fez-se a crítica: “[...] b) Deficiência de perspectiva sistémica. Principal responsável: legislador. Não é certamente possível reformar todo o sistema em simultâneo. Mas, quando se intervém em determinado sector, essa intervenção tem que incorporar uma visão global, não só de todo o sistema, mas, por maioria da razão, do subsector onde se está a intervir, sob pena de gerar incongruências na aplicação da lei. Apesar de algumas melhorias nesse campo, de que é exemplo a reforma do mapa judiciário, ainda está muito enraizada a tradição portuguesa de alterações ou de reformas mais ou menos avulsas, sem que no seu lastro haja um conhecimento sólido e integrado de todo o campo ao qual se dirigem. O continuum do processo de reforma, que se seguiu à reforma penal, veio agravar algumas incongruências internas do sistema. Mas, acima de tudo, a reforma não teve em conta nem procurou cuidar de desarticulações várias, algumas delas há muito diagnosticadas, como, por exemplo, entre os tribunais e o sistema prisional e entre os vários órgãos de polícia criminal (OPC) e os serviços do MP” (SANTOS; GOMES (Coord.), 2009, p. 10); “[...] c) Detenção fora de flagrante delito. A reforma de 2007 veio dificultar a detenção fora de flagrante delito, ainda que haja perigo de continuidade da actividade criminosa. Posteriormente, a lei das armas e a lei que estabelece o regime de prevenção da violência doméstica vieram permitir essa possibilidade. Não há razões materiais significativas para tal diferenciação 
Um exemplo poderá aclarar o argumento: um grupo de estudantes que vive em uma república, fazendo-se dessa seu lar; o cometimento de bullying ou outra forma violência por parte de um dos estudantes, a outro, poderia, aceitando-se a tese, ensejar a medida protetiva de afastamento do lar, constante do inciso II do artigo 22 da Lei $\mathrm{n}^{\circ}$ 11.340/06; claro que, assim como em qualquer aplicação de medidas cautelares, faz-se indispensável a demonstração da necessidade acauteladora, dos requisitos da proporcionalidade etc. Mas como tal medida está prevista no âmbito da Lei contra a violência doméstica contra a mulher ${ }^{45}$, em não se aceitando o quanto posto, impossível sua aplicação.

Neste exemplo, não há que se falar em aplicação de medida não prevista ou em poder geral de cautela, mas, tão somente, em aplicação de medida prevista de modo a abranger situações a que a mera literalidade do preceito não a autorizaria; não por proibição, mas pela forma como o emaranhado processo legislativo se dá.

Outra forma de interpretação extensiva é a proposta por Cruz (2011, p. 182-183), quando, em atenção ao inciso II do artigo 319 do CPP, propõe que a "[...] proibição de acesso ou frequência a determinado lugar", constante desta medida, se estenda à proibição de acesso à internet pelo acusado, vez que, poderia alguém "[...] duvidar que, com recursos tecnológicos do mundo moderno, uma pessoa pode estar virtualmente presente em qualquer lugar do planeta?", questiona o autor,

normativa. A diferenciação tem efeitos contraproducentes sobre a actuação de quem no terreno (em regra as forças policiais) se depara com situações de complexa catalogação nos diferentes regimes legais vigentes, mas que exigem tomada de decisões imediatas em contextos, por vezes, de grande tensão. [...] Consideramos, ainda, que opção legislativa de não inscrever no CPP determinadas condições particulares de admissibilidade da detenção fora de flagrante delito em sectores normativos específicos abre espaço para uma tendência de criação de novos regimes especiais, sempre que se considere conveniente alargar as margens da detenção em certo contexto, correndo-se, assim, o risco de pulverização dos pressupostos da detenção. Recomendamos a harmonização das regras legais vigentes, tanto quanto possível, no CPP" (SANTOS; GOMES (Coord.), 2009. p. 15-16).

45

De se lembrar, no entanto, que tal lei tem sido aplicada, ante o preceito da igualdade, à violência doméstica cometida pela mulher contra o marido, ou mesmo em caso de relações homossexuais, o que, por si só, alargou o âmbito de emprego da medida. 
fazendo referência aos crimes tipificados no artigo 241-A do Estatuto da Criança e Adolescente (ECA).

Concordamos, assim, com o quanto dito no estudo da Universidade de Coimbra ${ }^{46}$, repudiando a previsão de medidas acauteladoras em leis espalhadas, vez que terminam por criar regimes especiais, muitas vezes sucumbindo-se à pressão popular, correndo-se o risco de pulverização dos pressupostos de sua aplicação, ou, mesmo, da desordem sistêmica, acarretando severas injustiças.

A harmonização do sistema exige que todas as medidas estejam ou previstas em nosso Código de Processo, ou em leis avulsas ${ }^{47}$. Imprescindível, todavia, que já prevista em nossa estrutura (é o que chamamos, repita-se, de taxatividade mitigada), tornando-se impossível (e ilegal) a aplicação de medidas criadas pelo julgador.

\section{REFERÊNCIAS BIBLIOGRÁFICAS}

ÁVILA, Humberto. Teoria dos princípios: da definição à aplicação dos princípios jurídicos - $12^{\circ}$ edição. São Paulo: Malheiros, 2011.

BADARÓ, Gustavo Henrique. Prisão em flagrante delito e liberdade provisória no Código de Processo Penal: origens, mudanças e futuro de um complicado relacionamento. In: MALAN, Diogo; MIRZA, Flávio. (Coords.). Setenta anos do Código de Processo Penal brasileiro: balanço e perspectivas de reforma. Rio de Janeiro: Lumen Juris, 2011a.

BADARÓ, Gustavo Henrique. As novas medidas cautelares alternativas à prisão e o alegado poder geral de cautela no processo penal: a impossibilidade de decretação de medidas atípicas. Revista do Advogado, n. 113, p. 80, set. 2011b.

BADARÓ, Gustavo Henrique. Medidas cautelares alternativas à prisão preventiva - Comentários aos artigos 319-350 do CPP, na redação da Lei 12.403/11. In: FERNANDES, Og. (Coord.). Medidas cautelares no processo penal: prisões e suas alternativas: comentários à Lei 12.403/2011. São Paulo: Revista dos Tribunais, 2011c.

46 SANTOS; GOMES (Coord.), 2009. p. 15.

47 Esta última, como vimos, causadora do complexo emaranhado, mas que podem ser aplicadas a casos externos à lei (exemplo: medidas cautelares previstas na Lei Maria da Penha). 
BADARÓ, Gustavo Henrique. Processo Penal - 2a ed. Rio de Janeiro: Elsevier, 2014.

BARROS, Romeu Pires de Campos. Direito processual penal brasileiro. São Paulo: Sugestões Literárias, 1969.

BEDÊ JÚNIOR. Américo. Repercussões em matéria probatória do novo CPC no Processo Penal Brasileiro. In: CABRAL, Antonio Passo; PACELLI, Eugênio; CRUZ, Rogério Schietti (orgs.). Processo penal (Coleção Repercussões do Novo CPC, v.13). Salvador: Juspodivm, 2016.

BOTTINI, Pierpaolo Cruz. Medidas cautelares: superação da medíocre dicotomia. Boletim IBCCrim, edição especial CPP, ago. 2010.

CRUZ, Rogerio Schietti Machado. Prisão cautelar: dramas, princípios e alternativas. Rio de Janeiro: Lumen Juris, 2011.

DELMANTO, Fabio Machado de Almeida. Medidas substitutivas e alternativas à prisão cautelar. 2006. Dissertação (Mestrado em Direito) - Universidade de São Paulo, São Paulo.

FERNANDES, Antonio Scarance. Processo penal constitucional. São Paulo: Revista dos Tribunais, 2012.

GOMES FILHO, Antôno Magalhães. Presunção de inocência e prisão cautelar. São Paulo: Saraiva, 1992.

GOMES FILHO, Antôno Magalhães. Medidas cautelares e princípios constitucionais - Comentários ao artigo 282 do CPP, na redação da Lei 12.403/11. In: FERNANDES, Og. (Coord.). Medidas cautelares no processo penal: prisões e suas alternativas: comentários à Lei 12.403/2011. São Paulo: Revista dos Tribunais, 2011.

GONZÁLEZ-CUÉLLAR SERRANO, Nicolas. Proporcionalidad y Derechos Fundamentales en el processo penal. Madrid: Colex, 1990.

GRINOVER, Ada Pellegrini. A nova lei processual penal: comentários à Lei 6.416/77. São Paulo: Revista dos Tribunais, 1977.

KEHDI, André Pires de Andrade. A retenção do passaporte como medida cautelar alternativa à prisão provisória. Boletim IBCCrim, n. 172, mar. 2007.

LIMA, Marcellus P. O processo penal dos crimes de trânsito. Rio de Janeiro: Lumen Juris, 2001.

LOPES JUNIOR, Aury. A (in)existência de poder geral de cautela no processo penal. Boletim IBCCrim, n. 203, out. 2009. 
LOPES JUNIOR, Aury. A inserção do contraditório no regime jurídico das medidas cautelares pessoais. Boletim IBCCrim, n. 223, p. 5, jun. 2011.

MAXIMILIANO, Carlos. Hermenêutica e aplicação do direito. Rio de Janeiro: Forense, 2000.

MELLO, Celso Antônio Bandeira de. Considerações em torno dos princípios hermenêuticos. Revista de Direito Público, n. 21, p. 141-147, jul./set. 1972.

MENDES, Gilmar Ferreira; COELHO, Inocêncio Mártires; BRANCO, Paulo Gustavo Gonet. Curso de direito constitucional. São Paulo: Saraiva, 2009.

MENDONÇA, Andrey Borges. Prisão e outras medidas cautelares pessoais. São Paulo: Método, 2011.

MORAES, Maurício Zanoide de. Presunção de inocência no processo penal brasileiro: análise de sua estrutura normativa para a elaboração legislativa e para a decisão judicial. Rio de Janeiro: Lumen Juris, 2010.

QUEIROGA, Antônio Elias de. Aplicação do direito. Revista de Direito Civil, v. 4, n. 14, p. 31-40, out.-dez. de 1980.

RAMÍREZ, Juan J. Bustos, MALARÉE, Hernán Hormazábal. Lecciones de Derecho Penal - Vol. 1. Madrid: Trotta, 1997.

SANTOS, Boaventura de Sousa (Dir. Científico); GOMES, Conceição (Coord.). Monitorização da Reforma Penal. Relatório Complementar. Centro de Estudos Sociais, Faculdade de Economia de Coimbra. Coimbra, out. 2009.

THEODORO JÚNIOR, Humberto. Princípios gerais do direito processual civil. Revista de Processo, v. 23, jul. 1981.

TORNAGHI, Hélio Bastos. Instituições de processo penal - $2^{\mathrm{a}}$ ed. São Paulo: Saraiva, 1977.

TOURINHO FILHO, Fernando da Costa. Processo penal. São Paulo: Saraiva, 2012. 
DADOS DO PROCESSO EDITORIAL

(http://www.ibraspp.com.br/revista/index.php/RBDPP/about/editorialPolicies)

- Recebido em: 08/03/2017

- Controle preliminar e verificação de plágio: 09/03/2017

- Avaliação 1: 14/03/2017

- Avaliação 2: 14/03/2017

- Avaliação 3: 19/03/2017

- Avaliação 4: 27/03/2017

- Decisão editorial preliminar: 28/03/2017

- Retorno rodada de correções 1: 29/04/2017

- Decisão editorial preliminar 2: 30/04/2017

- Retorno rodada de correções 2: 05/05/2017

- Decisão editorial final: 06/05/2017

\section{Equipe editorial envolvida}

- Editor-chefe: 1 (VGV)

- Revisores: 4

\section{COMO CITAR ESTE ARTIGO:}

CASTRO, Pedro M. A. Medidas cautelares pessoais, poder geral de cautela e a taxatividade mitigada. Revista Brasileira de Direito Processual Penal, Porto Alegre, vol. 3, n. 2, p. 691-716, mai./ago. 2017. https://doi.org/10.22197/rbdpp.v3i2.60

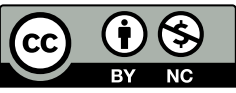

Esta obra está licenciada com uma Licença Creative Commons Atribuição-NãoComercial 4.0 Internacional. 